Article

\title{
Donate Time or Money? The Determinants of Donation Intention in Online Crowdfunding
}

\author{
Yuangao Chen $₫$, Ruyi Dai, Jianrong Yao and Yixiao Li * \\ School of Information, Zhejiang University of Finance and Economics, Xiasha Higher Education Zone, \\ Hangzhou 310018, Zhejiang, China \\ * Correspondence: yxli@zufe.edu.cn
}

Received: 15 June 2019; Accepted: 4 August 2019; Published: 7 August 2019

check for updates

\begin{abstract}
Compared with traditional charities, donation-based crowdfunding has many novel characteristics. Among the variety of factors that influence potential donors before they develop a donation intention, which are the main ones influencing the intention to donate online? The purpose of this paper is to investigate the key potential determinants of both time and money donations. This study attempts to combine the theory of planned behavior and norm activation theory with social presence theory to conceptualize and develop an integration framework to measure the donation intention. The results of the structural equation modeling, based on 350 valid questionnaire responses received from November 19 to December 19, 2018, suggest that the dependent variable of time donations is significantly affected by social presence, trust, and perceived behavioral control. As for the dependent variable of money donations, only subjective norm has an insignificant effect. The study results offer practical guidelines about the unique aspects of donation to managers of crowdfunding platform and fundraisers.
\end{abstract}

Keywords: donation-based crowdfunding; social presence; norm activation; trust; money donations; time donations

\section{Introduction}

Individuals urgently need to understand how to adopt pro-socially and pro-environmental behaviors regarding the global concerns surrounding the issue of sustainable development [1]. Of late, crowdfunding has emerged as a valuable alternative source of funding for entrepreneurs seeking external financing [2]. It is different from traditional financing methods because it lets fundraisers present their projects on a platform. These platforms, which do not have the standard financial intermediaries, allow individuals to directly fund projects through the Internet, even if the amounts involved are relatively small. The connection between fundraisers and backers takes place in cyberspace. The funding seekers post all their projects on the platform. Visitors can browse through many projects when they log into the homepage of the crowdfunding website. If they are interested in a particular project or want to know more about a project, they can click on it to view the project details page and even get updates on this project. Some crowdfunding platforms also provide a channel for borrowers and visitors to communicate, thereby providing potential donors with a comprehensive description of the project. According to a report from zhongchoujia.com [3], the total financing for successful donation-based crowdfunding projects was approximately 186 million yuan in the first half of 2018 , an increase of $16.8 \%$ compared with the same period last year. From this, we can conclude that donation-based crowdfunding is an important new channel of public welfare activities, showing a better development trend.

Donation-based crowdfunding has emerged from the broader field of crowdsourcing, which refers to a public appeal, initiated through the medium of web-enabled information systems, to make donations 
over a fixed time limit [4]. The differences between donation-based crowdfunding and traditional donation environment challenge the interpretation of donation behavior in traditional charity-giving. First, many of the donation-based crowdfunding sites are based on anonymous donations, which means that individuals' concern for their social image is rare [5]. Second, although geography and social networks have been shown to predict crowdfunding donations, most funders donate to recipients who have little social contact with them. The above two points challenge reciprocity-based explanations of giving. Third, charitable donors on crowdfunding websites proactively seek the target donation projects without waiting for donation requests. Finally, the platform of donation-based crowdfunding also allows for communication between participants besides updating the real-time progress of each project. Thus, potential funders can learn the level of support from other funders and the time left before making a donation decision [6].

Although donation-based crowdfunding's popularity is growing, there are many charity projects that fail to achieve their financing goals within a stipulated period. In order to effectively increase the success of the project, extant research focuses on a variety of factors that influence potential backers' donation behavior. Previous literatures have investigated donation-based crowdfunding from several perspectives, namely donor's conformity behavior [7] and social networks [8]. However, crowdfunding in China is different from its counterpart in the West [9]. Scholars have studied donation-based crowdfunding from the following aspects: technological characteristics (website quality and transaction convenience), project attributes (such as initiator reputation, project popularity, and project content quality), and the influence of agenda-setting on public policy $[10,11]$. However, there are a few studies that compare traditional charity with the factors affecting donation-based crowdfunding. Thus, it is necessary to establish a theoretical model to systematically synthesize individual donation intention in donation-based crowdfunding to get a panoramic overview. Further, given the paucity of existing studies on the three parties (fundraisers, crowdfunding platforms, and backers), the question about the factors influencing people's donating behavior has not been fully answered.

In academia, extant studies explain behavior intention, such as purchasing intention or entrepreneurial intention, by using the theory of planned behavior (TPB) [12-14]. TPB posits that individual behavior is driven by behavioral intentions. Further, these intentions are jointly influenced by three aspects: an individual's attitude toward the behavior, the subjective norms surrounding the performance of the behavior, and the individual's perception of the degree of ease with which the behavior can be performed (behavioral control). The norm activation theory (NAT) explains altruistic and environment-friendly behavior $[15,16]$. In social-virtual environments, social presence theory (SPT) is adopted to study users' behaviors $[17,18]$. To highlight the characteristics of online donation-based crowdfunding behavior, this paper integrates social presence and trust from SPT; attitude, subjective norms, and perceived behavioral control from TPB; and personal norms from NAT to ascertain factors influencing the intention to donate in the crowdfunding context.

This study expands the research on factors that affect the backers' intention to donate in crowdfunding projects in two ways. First, it seeks to be one of the first to introduce the combination of TPB, SPT, and NAT to the donation-based crowdfunding literature, which is an emerging field of research. Because of this, the theories and theoretical models in the literature studying the field of crowdfunding are in the initial stage. Second, this paper divides the intention to donate into time donations and money donations. To overcome the excessive unilateral focus on the intention to donate, we consider time donations, which can complement money donations.

The remainder of this paper is organized as follows. Section 2 provides a literature review of the current research in donation-based crowdfunding. Section 3 proposes the research model and outlines the hypotheses. Section 4 states the research methodologies and elaborate processes. The data analysis and findings are presented in Section 5. Section 6 discusses the implications and the limits. Finally, the conclusions of this paper are summarized in Section 7. 


\section{Literature Review}

Crowdfunding can be divided into four main types: reward-based, lending-based, equity-based, and donation-based [19]. In the donation-based crowdfunding context, the investors in the crowdfunding activities differ from those in the other three types of crowdfunding. Philanthropy has been framed from three competing perspectives: altruism, self-interest, and reciprocity [20]. Altruism refers to behaviors that mainly consider the needs of others rather than one's own. Self-interest is defined as an unusual economic exchange behavior. Reciprocity views the giving as a social exchange act. The backers donate their money and time in the crowdfunding because of altruistic factors instead of a desire for rewards. In recent years, rapid development of donation-based crowdfunding has gradually become an effective way for an individual recipient or a non-profit organization to raise donations.

From the perspective of backers, Meer [21] described that both an increased donation price and intensified competition reduces the success likelihood of a crowdfunding campaign. Sasaki [7] discovered the relationship between donors' multiple previous donations and subsequent contribution behavior on the crowdfunding platform JapanGiving. Liu et al. [10] verified that the quality attributes of crowdfunding websites in terms of security, navigability, visual appeal, and transaction convenience are key factors influencing individuals' empathy for donation-based crowdfunding campaigns. As for the fundraisers, they pay attention to the presence of rational and credible appeals in the message. Majumdar and Bose [22] concluded that the extent of rational, emotional, and credibility appeal affects the likelihood of a project being funded and the mere existence of negative appeal cannot do so. As we can see from existing academic studies, most prior researchers tried to find underlying factors associated with the success of crowdfunding. Donation-based crowdfunding might be considered, a priori, to have caught on relatively less than the other crowdfunding models studied. It is interesting to point out that donation-based crowdfunding adds an online condition, which traditional crowdfunding does not. However, there are few studies on these factors.

Donations to charities can be divided into different forms, such as donations of time, money, or in-kind goods and services [23]. Money donation decisions are argued to be more rational than emotional, and vice versa for time donations [24]. Researchers found time donations activate goals related to emotional health, whereas money donations motivate goals related to economic utility [25]. Feldman [26] established an econometric model to show that time donations and money donations are substitutes. Even when donating time instead of earning money leads to a large loss, subjects display a stronger willingness to donate time than donate money [27]. Drawing on the differences between time and money donations, scholars demonstrated that in the case of time donations, more human and social capitals are needed than money donations [28]. Based on the fundamental difference between time and money giving, this study discovers funders' donation intentions from two independent aspects, time donation intentions and money donation intentions. The purpose of this research is to make a beneficial comparison between these two donation intentions.

Backers participate in a donation-based crowdfunding campaign out of kindness and without expectation of rewards, which differs from the other three crowdfunding modes. Furthermore, the process complexity and risk are both low in the donation-based context. Considering the distinctness of donors' willingness to donate time or money, the framework of this study is presented from two primary aspects. First, traditional philanthropists are mostly individuals or foundations. They make regular and large-scale donations to individual businesses or poor groups through non-profit organizations or foundations. The information exchange of this mode is limited and one-way, while donors in donation-based crowdfunding are individuals in the network. They can bypass the foundation's donations to individuals or even a variety of individual entities or other forms of existence. Furthermore, donation-based crowdfunding has been welcomed by the public due to its advantages of greater transparency, diversified projects, and freedom from time and space constraints. These characteristics of donation-based crowdfunding make up for the shortcomings of traditional charity. Therefore, this paper focuses on the differences between traditional charity and donation-based 
crowdfunding. On the basis of previous studies focusing on the factors affecting traditional donation behavior (i.e., attitude, subjective norm, perceived behavioral control, and personal norm), the new characteristics of donation-based crowdfunding were considered. In this scenario, the theoretical model that we adopt to explore donation intentions is an integrated model of SPT, TPB, and NAT. Second, in order to more fully understand the backer's intention to donate, two novel dimensions (time donations and money donations) are introduced. In addition, the relationship between the two different intentions and the corresponding determinants are verified. As donation-based crowdfunding is in an emerging field, there is little research in this area. Therefore, it is very necessary to carry out this research.

\section{Research Model and Hypotheses}

\subsection{Social Presence Theory}

Social media network is a social virtual environment where individuals or groups communicate and share experiences. One of the greatest challenges faced when making donations in cyberspace is the imitation of social abilities that create a feeling of empathy, which is common in traditional offline donations. Social presence describes how the use of the media is influenced by the social environment [29]. Furthermore, social presence refers to the extent to which the media allows users to establish personal contact with other users [30,31]. According to the study of Schroeder [32], social presence additionally indicated the psychological feelings of interacting with others in an intermediary environment. Animesh et al. [33] defined social presence as "the perceived sense of personal, warm, intimate, sociable, or sensitive about the social interactions in the virtual context." Thus, following Heijden [34], this paper defines the social presence of a website as "the extent to which a website allows users to psychologically experience others."

Based on the social psychological theories of interpersonal communication and symbolic interactionism, SPT as a theory to describe intermediary communication also stretches to the study of social media to explain the social presence concept $[35,36]$. SPT evolves from the use of telecommunications. It outlines how individuals use social media because individuals view it as a behavioral or sensory experience that projects an intellectual and social acceptance [37]. According to SPT, media users should test the degree of social presence required by the task and combine it with the social presence level of the media to understand the extent to which the medium enables communicators to experience the psychological existence of communicative partners [29].

\subsubsection{Social Presence}

Researches have shown the important influence of social presence on a website on the attitude of online shoppers. Gefen and Straub [38] found social presence has an effect on purchasing intentions in e-product and e-service settings. Choi [39] showed that social presence increases social networking service (SNS) continuance intention. Two concepts associated with the social presence are "intimacy" and "immediacy." Intimacy refers to the closeness individuals feel to similar users, and immediacy refers to the psychological distance among similar users [40]. It is important to help target users feel the warmth and sociality of human beings and generate a sense of social presence, which is positively related to trust and intention [39].

However, social presence, as a potential factor influencing donating intention in online crowdfunding, has not been studied much. In this study, we study the effects of social presence on donation-based crowdfunding. In fact, in order to present a high sense of social presence, many websites add "social touch" to their interactions. This involves using a consumer's name to welcome him or her on entering the site, as well as subsequently providing personalized websites and email exchanges [39]. Creating an interactive atmosphere can help individuals in making decisions about a donation. Thus, social presence plays an antecedent role in a user's attitude toward donation 
decision-making [41]. Studies on intention and trust among online users show that social presence influences intention by affecting the trust of users [42,43]. Therefore, we hypothesize:

Hypothesis 1 (H1a). Social presence positively affects a donor's intention toward time donations.

Hypothesis 1 (H1b). Social presence positively affects a donor's intention toward money donations.

\subsubsection{Trust}

Adding features that evoke a sense of social presence on a website may increasing donation intention by increasing a crowdfunder's trust [41]. The association between social presence and trust has been examined in various studies. For example, Gefen and Straub [41] have suggested that high social presence might increase user trust because social presence serves as a cue that potential funders' perceptions of project trust will increase as social presentation increases.

Trust, defined in the study as the credibility of a crowdfunding project as per the judgment of potential funders, has been extensively studied in the context of online transactions [42,43]. Trust conceptualized as a one-dimensional construct results in certain behavioral intentions on the part of consumers in e-commerce $[44,45]$. Social presence can build trust by creating a sense of personal connection with other users and sensitive interpersonal contact through the website [46]. Although most of the information posted on crowdfunding platforms is trustworthy, it is not unusual for such platforms to spread misinformation and indulge in fraud. In addition, donation-based crowdfunding is a transaction between strangers taking place through the crowdfunding platform. Information acquisition, decision-making, and judgment, as well as capital transfer, are all conducted through the virtual network, which not only improves the financing efficiency, but also greatly increases the probability of information asymmetry and fraud for all parties involved in the transaction. Hence, when reviewing crowdfunding projects, potential donors often depend on the sense of trust provided by the platforms and fundraisers to decide whether to donate their resources to a certain project.

Typically, consumers are willing to buy goods from unknown sellers within an e-marketplace, despite the obvious risks, because of the premise of mutual trust. There are extensive studies that verify the significant influence of trust on behavioral intention. Sullivan and Kim [47] found that trust is the main predictor of online repurchase intention. A study on individual donation behavior found that trust is related to donation intention and that it will increase the intention to donate [10]. Thus, one of the main factors influencing intentions to donate is trust, which is expected to have a positive impact on the intention to donate. Hence, we apply this conclusion to verify whether trust has the same effect on separate two donation behaviors, time donations, and money donations. Based on this, we propose the following assumptions:

Hypothesis 2 (H2). Social presence positively affects a donor's trust in donation-based crowdfunding.

Hypothesis 3 (H3a). Trust positively affects a donor's intention toward making time donations.

Hypothesis $3 \mathbf{~ ( H 3 b ) . ~ T r u s t ~ p o s i t i v e l y ~ a f f e c t s ~ a ~ d o n o r ' s ~ i n t e n t i o n ~ t o w a r d ~ m a k i n g ~ m o n e y ~ d o n a t i o n s . ~}$

\subsection{Theory of Planned Behavior}

In the context of $\mathrm{TPB}$, the intention of individuals is considered to be the willingness to perform a certain action, which directly affects the actual conduct of providing services. The most direct determinant of behavior in TPB is intention. Intention, in turn, is influenced by combining the three independent measures: "attitude," "subjective norm," and "perceived behavioral control" [48]. Attitude refers to an individual's positive or negative evaluation of behavior. It is a kind of psychological emotion generated by consumer evaluation and, if it is positive, behavior intention tends to be more positive [49]. A subjective norm refers to the perception of whether social pressures would be enforced, 
that is, the support of family or society to donate. Perceived behavioral control, noted as performing an action, is simple or complex due to whether it combines past donations that relate to hindrance and predictable obstacle $[48,50]$. Webb et al. [51] is the first study to apply TPB in the area of charity-giving.

\subsubsection{Attitude}

The most important factor of behavior intention in TPB is attitude [52]. Attitude toward the behavior refers to the "degree to which a person has a favorable or unfavorable evaluation of the behavior in question" [48]. In fact, Saha and Chandra [53] verified that intention is positively influenced by attitude. Attitude to a behavior is predicted by two beliefs: the possible consequences of the behavior and the assessments of those consequences [54]. Depending on circumstances, an individual can hold multiple contradictory attitudes with no cognitive dissonance [55]. Hence, it is hypothesized that:

Hypothesis 4 (H4a). Attitude positively affects a donor's intention toward making time donations.

Hypothesis $4 \mathbf{( H 4 b ) . ~ A t t i t u d e ~ p o s i t i v e l y ~ a f f e c t s ~ a ~ d o n o r ' s ~ i n t e n t i o n ~ t o w a r d ~ m a k i n g ~ m o n e y ~ d o n a t i o n s . ~}$

\subsubsection{Subjective Norm}

In the TPB model, the second factor that determines the behavioral intention is the subjective norm. The definition of the subjective norm refers to the perception of social pressure and the intention to perform or not perform a behavior [48]. A subjective norm is based on the influence of others, such as "friends," "family," and "colleagues," who are close or significant to the person. A subjective norm captures an individual feeling about the social pressure from a behavior. Moreover, consumers having positive subjective norms toward a given behavior are more likely to be a positive revisit intention [56].

In individual behavioral intention context, many studies have documented subjective norms as an important determinant of intention. These include studies on organic food purchase intention $[57,58]$, green hotel revisit intention [49,59], and blood donors' intention [51]. All of them show a positive relationship between subjective norm and behavior intention. Therefore, the following hypotheses are proposed:

Hypothesis 5 (H5a). Subjective norms are positively related to time donations.

Hypothesis $\mathbf{5}(\mathbf{H} 5 \mathbf{b})$. Subjective norms are positively related to money donations.

\subsubsection{Perceived Behavioral Control (PBC)}

Among the three factors in TPB, PBC is the most important when the user's behavior is partially under the control of the will [50]. The term "perceived behavioral control" is conceptualized as the perceived ease or difficulty of performing the behavior and reflects past experiences and expected obstacles $[48,50]$. When potential donors perceive that their behaviors are beneficial, they are more likely to adopt these behaviors.

Many literatures showed that $\mathrm{PBC}$ is positively correlated with intentions in various fields, such as conservation [60], green hotel [49,59], and blood donors' intention [53]. Thus, the following hypotheses are proposed:

Hypothesis 6 (H6a). Perceived behavioral control is positively related to time donations.

Hypothesis 6 (H6b). Perceived behavioral control is positively related to money donations.

\subsection{Norm Activation Theory (NAT)}

The concept of a personal norm is deleted from TPB as it does not have the ability to improve the prediction of intention, and it is an alternative measure for behavior intention [61]. The current research 
is based on our hypothesis that personal norms may increase our understanding of donation behavior. NAT focuses on sacrificing one's own interests for the happiness of others [62]. Thus, it focuses on altruistic behavior (e.g., energy-saving behavior and recycling behavior) $[63,64]$. Donation behavior is a combination of prosocial concerns and altruism [65]. The model includes three variables: awareness of consequences, attribution of responsibility, and personal norms. The definition of awareness of consequences is that when a person is aware of negative consequences, he does not employ prosocial behavior, and these consequences will negatively affect others or things he values. Attribution of responsibility refers to people that are responsible for the negative effects of not implementing prosocial behavior [66]. Among these, the personal norm is the core variable of NAT. NAT assumes that individual behavior is predicted by personal norms (i.e., internal standards for specific behaviors) rather than by subjective norms that impose rules externally [67].

Fishbein [68] first formulated a theory, which comprised one attitudinal and two normative components. Specifically, these two normative components include one personal and one social attribute. The influence of a personal norm component on behavioral intention is thought to depend on the individual's motivation to comply with these norms. In Schwartz's theory, a personal norm refers to the moral act of performing a particular act or failing to do so [69]. Based on the consistency of a person's behavior with his or her personal norms, the person may feel a sense of pride or guilt [70]. Consumer behavior researchers, who have considered the motivations of donors, have found that the perceived benefits of donation include a sense of self-esteem, public acceptance, and satisfaction in expressing gratitude for one's own well-being, and a reduction in feelings of guilt and obligation [71,72]. Parker et al. [73] studied the personal norm variable by using the TPB model to predict the intentions regarding three types of traffic violation. In other domains, personal norms appear to have an influence on behavior intention too. Wang et al. [64] found that personal norms have a significant impact on the habitual energy-saving behavior of urban residents. The hallmark of altruism is that it requires individuals to give extra time and make more effort but does not immediately reward them [63]. Altruistic behaviors are about caring for others. Hence, donating is a type of altruistic behavior. The specific assumptions are as follows:

Hypothesis 7 (H7a). Personal norms are positively related to time donations.

Hypothesis 7 (H7b). Personal norms are positively related to money donations.

Figure 1 depicts our research model and shows the factors determining the intention to donate (both time donations and money donations), which are affected by attitude, subjective norms, perceived behavioral control, personal norms, trust, and social presence.

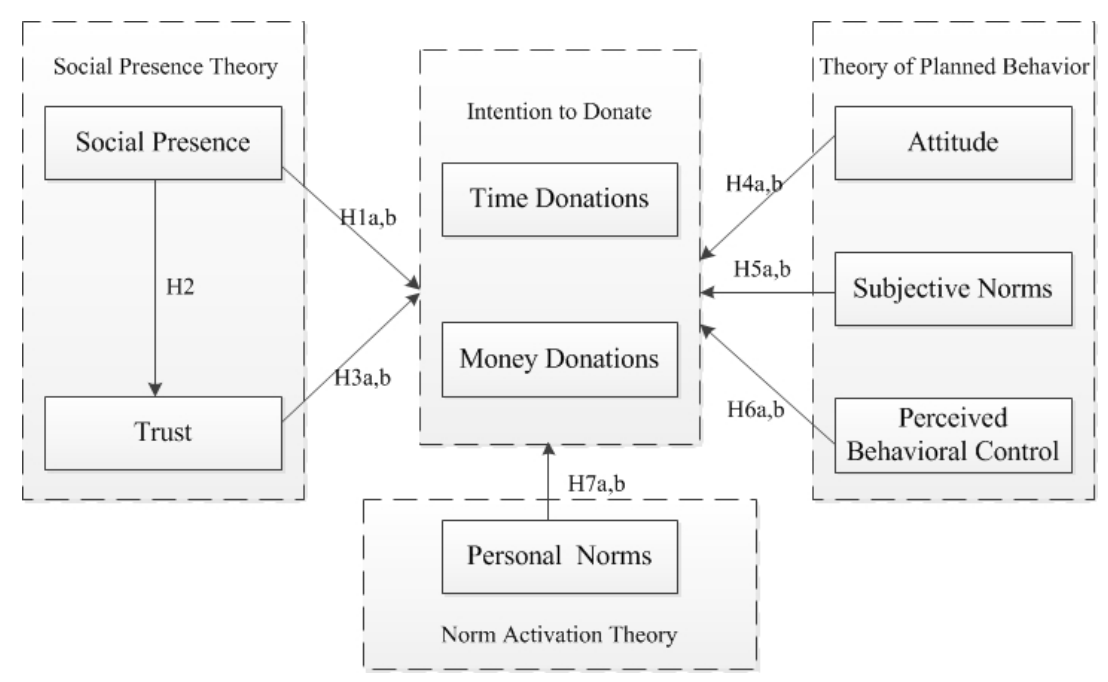

Figure 1. Research model. 


\section{Research Method}

\subsection{Measurement}

Based on the previous assumptions, we used a questionnaire to investigate the validity of the proposed model. The research model included six independent and two dependent variables. Constructs of attitude, subjective norms, and personal norms were measured using four items adopted from Wang et al. [63]. Perceived behavioral control was measured using four items adopted from Mittelman and Rojas-Méndez [74]. Social presence was measured using five items adopted from Gefen and Straub [38]. Trust was measured using three items adopted from Lee [75]. Time donations and money donations were measured using three items adopted from Liu et al. [10]. The questionnaire had 31 items that were rated by respondents on a seven-point Likert scale (a score of 1 represented "strongly disagree," while a score of 7 represented "strongly agree"). All the items were based on existing measurements and literatures. The sources of all items are listed in Appendix A. As these items were written in English, the questionnaire items were first translated into Chinese. We made minor changes to suit the specific context. After the questionnaire was drafted, we invited some experienced users and experts to review the questionnaire. Based on their feedback, we made further modifications to ensure an accurate reflection of behavior determinants in the context of donation-based crowdfunding. After the pretest, minor revisions were made to the questionnaire.

The final questionnaire comprised two parts. The first part covered demographic information of the respondents. The second part had construct items that measured respondents' identification with the questionnaire items.

\subsection{Sample Collection}

To test our hypotheses, we followed two approaches to collect data from November 19 to December 19, 2018. First, an online questionnaire link was created on an online survey website (www.sojump.com) and a paid sample collection service was employed to guarantee the quality of data. According to the paid service, the survey website charged a certain percentage of the sample service fee from it, and the remaining funds were all given to the respondents. The website had over 2.6 million members, and, on average, over 1 million people filled out questionnaires on the site daily. This survey website randomly invited some of them to join the sample database. The survey website placed the questionnaire links on the sample pool, and the survey respondents filled out the surveys according to their own choices. The website was not manually controlled. This guaranteed the randomness of the questionnaire object. The second way of collecting data targeted users of social networks, such as WeChat and QQ. Considering that donation-based crowdfunding is an emerging phenomenon, a brief introduction and two pictures (the first one was a screenshot of the www.zhongchu.cn/gongyi homepage and the other was a screenshot of donation-based crowdfunding project forwarded to moments) were posted at the beginning of the questionnaire. Respondents were asked to recall the latest donation-based crowdfunding project about which they had read (regardless of whether they had donated money) and were then asked to fill out the questionnaire. The total number of questionnaires collected was 520. After eliminating 170 invalid responses from users who never joined in these projects and all unreasonable questionnaires (finishing the survey in an unrealistically short period or providing the same answers to all the questions), 350 valid responses were collected in a month. The effective questionnaire accounted for $67.3 \%$ of the total. Table 1 lists the demographic information of the respondents. 
Table 1. Sample demographics.

\begin{tabular}{cccc}
\hline Measure & Item & Number $(\boldsymbol{N}=\mathbf{3 5 0})$ & Percentage (\%) \\
\hline \multirow{2}{*}{ Gender } & Male & 131 & 37.43 \\
& Female & 219 & 62.57 \\
\hline \multirow{2}{*}{ Age } & $<18$ years & 9 & 2.57 \\
& $18-30$ years & 231 & 66 \\
& $31-50$ years & 103 & 29.43 \\
Education level & $>50$ years & 7 & 2 \\
& Junior high school or below & 9 & 2.57 \\
& Senior high school & 31 & 8.68 \\
& Two-year college & 47 & 13.43 \\
& Four-year college & 224 & 64 \\
& Graduate school or above & 39 & 11.14 \\
\hline \multirow{2}{*}{ Donation experience } & $<1$ year & 64 & 18.29 \\
& $1-2$ years & 171 & 48.86 \\
& $3-5$ years & 71 & 20.29 \\
& $6-10$ years & 27 & 7.71 \\
& $>10$ years & 17 & 4.86 \\
\hline & $<30$ thousand & 123 & 35.14 \\
& $30-60$ thousand & 69 & 19.71 \\
& $60-120$ thousand & 117 & 33.43 \\
& $120-200$ thousand & 27 & 7.71 \\
\hline
\end{tabular}

\section{Data Analysis and Results}

Compared to the covariance-based structural equation modeling (SEM), the component-based partial least squares (PLS) has no strict requirements about the sample size and distribution [76]. In fact, the PLS method is suitable for predicting the validity of models. This paper used PLS to analyze the data because of its advantage in allowing researchers to use small samples to examine a complex model. This paper adopted a two-step method to analyze the model. The first step was to analyze the measurement model, including the test of reliability and validity. The second step was to test the structural model and evaluate the structural relationship between the potential constructs and hypotheses.

\subsection{Measurement Model}

PLS was used to test convergent validity and discriminant validity [77]. Convergent validity was assessed using factor loading, composite reliability (CR), Cronbach's alpha, and average variance extracted (AVE) [78]. As shown in Table 2, factor loadings for all items ranged from 0.558 to 0.915 , which exceeded the recommended level of 0.5 . Cronbach's alpha for each construct ranged from 0.763 to 0.888 , which exceeded the recommended level of 0.7 . CR for each construct ranged from 0.849 to 0.93 , which exceeded the recommended level of 0.7. The AVE for each construct ranged from 0.589 to 0.817 , which exceeded the recommended level of 0.5. Table 3 shows that the square root of the AVE for each construct exceeded the correlations between it and other constructs. The AVE value of each construct was greater than the shared variation value among constructs, showing that the square root value of the mean variance sampling quantity of the potential variables of the construct in this study was greater than the value of the correlation value, with "discriminant validity." To further examine the discriminant validity, the cross-loading matrix was used and is listed in Appendix B. Each item's loading on one factor was stronger than its loadings on other factors, thereby presenting a clear loading matrix. Thus, convergent validity and discriminant validity were supported. The goodness-of-fit (GOF) is as an index for validating a PLS path model globally $[79,80]$. The GOF index of this model was 
0.588 , which exceeded the threshold of GOF $(>0.36)$ suggested by previous studies [81,82]. Thus, it was verified that the research model fit the data well.

Table 2. Item reliability analysis.

\begin{tabular}{|c|c|c|c|c|c|}
\hline Variable & Item & Standard Loading & Cronbach's Alpha & Composite Reliability & AVE \\
\hline \multirow{4}{*}{$\begin{array}{l}\text { Attitude } \\
\text { (AT) }\end{array}$} & AT1 & 0.811 & \multirow{4}{*}{0.78} & \multirow{4}{*}{0.857} & \multirow{4}{*}{0.603} \\
\hline & AT2 & 0.603 & & & \\
\hline & AT3 & 0.84 & & & \\
\hline & AT4 & 0.829 & & & \\
\hline \multirow{4}{*}{$\begin{array}{l}\text { Subjective Norms } \\
\text { (SN) }\end{array}$} & SN1 & 0.824 & \multirow{4}{*}{0.78} & \multirow{4}{*}{0.859} & \multirow{4}{*}{0.608} \\
\hline & SN2 & 0.854 & & & \\
\hline & SN3 & 0.809 & & & \\
\hline & SN4 & 0.608 & & & \\
\hline \multirow{4}{*}{$\begin{array}{l}\text { Personal Norms } \\
(\mathrm{PN})\end{array}$} & PN1 & 0.811 & \multirow{4}{*}{0.788} & \multirow{4}{*}{0.862} & \multirow{4}{*}{0.611} \\
\hline & PN2 & 0.773 & & & \\
\hline & PN3 & 0.799 & & & \\
\hline & PN4 & 0.742 & & & \\
\hline \multirow{4}{*}{$\begin{array}{c}\text { Perceived } \\
\text { Behavioral Control } \\
\text { (PBC) }\end{array}$} & PBC1 & 0.857 & \multirow{4}{*}{0.763} & \multirow{4}{*}{0.849} & \multirow{4}{*}{0.589} \\
\hline & PBC2 & 0.558 & & & \\
\hline & PBC3 & 0.828 & & & \\
\hline & PBC4 & 0.791 & & & \\
\hline \multirow{5}{*}{$\begin{array}{l}\text { Social Presence } \\
\text { (SP) }\end{array}$} & SP1 & 0.793 & \multirow{5}{*}{0.826} & \multirow{5}{*}{0.878} & \multirow{5}{*}{0.59} \\
\hline & SP2 & 0.767 & & & \\
\hline & SP3 & 0.776 & & & \\
\hline & SP4 & 0.773 & & & \\
\hline & SP5 & 0.727 & & & \\
\hline \multirow{3}{*}{$\begin{array}{l}\text { Trust } \\
\text { (TR) }\end{array}$} & TR1 & 0.915 & \multirow{3}{*}{0.873} & \multirow{3}{*}{0.922} & \multirow{3}{*}{0.798} \\
\hline & TR2 & 0.893 & & & \\
\hline & TR3 & 0.871 & & & \\
\hline \multirow{3}{*}{$\begin{array}{c}\text { Time Donations } \\
\text { (TD) }\end{array}$} & TD1 & 0.891 & \multirow{3}{*}{0.87} & \multirow{3}{*}{0.92} & \multirow{3}{*}{0.794} \\
\hline & TD2 & 0.892 & & & \\
\hline & TD3 & 0.889 & & & \\
\hline \multirow{3}{*}{$\begin{array}{l}\text { Money Donations } \\
\text { (MD) }\end{array}$} & MD1 & 0.914 & \multirow{3}{*}{0.888} & \multirow{3}{*}{0.93} & \\
\hline & MD2 & 0.889 & & & 0.817 \\
\hline & MD3 & 0.908 & & & \\
\hline
\end{tabular}

Table 3. Inter-construct correlations.

\begin{tabular}{ccccccccc}
\hline & AT & MD & PBC & PN & SN & SP & TD & TR \\
\hline AT & $\mathbf{0 . 7 7 7}$ & & & & & & & \\
MD & 0.624 & $\mathbf{0 . 9 0 4}$ & & & & & & \\
PBC & 0.571 & 0.653 & $\mathbf{0 . 7 6 7}$ & & & & & \\
PN & 0.745 & 0.67 & 0.638 & $\mathbf{0 . 7 8 2}$ & & & \\
SN & 0.69 & 0.593 & 0.597 & 0.654 & $\mathbf{0 . 7 8 0}$ & & & \\
SP & 0.56 & 0.685 & 0.663 & 0.64 & 0.597 & $\mathbf{0 . 7 6 8}$ & & \\
TD & 0.494 & 0.72 & 0.658 & 0.544 & 0.503 & 0.632 & $\mathbf{0 . 8 9 1}$ & $\mathbf{0 . 8 9 3}$ \\
TR & 0.562 & 0.63 & 0.579 & 0.624 & 0.592 & 0.635 & 0.558 & \\
\hline
\end{tabular}

Note: Diagonal elements in bold are the square roots of AVE. In order to obtain sufficient discriminant validity, these values should exceed the inter-context correlation. AT-Attitude; MD-Money donations; PBC-Perceived behavioral control; PN—Personal norm; SN—Subjective norm; SP—Social presence; TD—Time donations; TR—Trust.

\subsection{Structural Model}

As the measurement model was confirmed with satisfactory results, we next studied the structural model, whose results included path loading, corresponding $t$-values, and $R^{2}$. The final test results are shown as in Figure 2. Nine out of thirteen hypotheses were supported $(p<0.05)$, while the remaining 
four were insignificant. First, social presence had positive effects on time donations $(\beta=0.262, p<0.001)$ and money donations $(\beta=0.26, p<0.001)$, thus supporting hypothesis H1a and H1b. Social presence ( $\beta=0.635, p<0.001)$ exhibited strong positive effects on trust and explained $40.4 \%$ of the variance in trust. Consequently, $\mathrm{H} 2$ was supported empirically. In addition, trust was associated positively with time donations $(\beta=0.144, p<0.001)$ and money donations $(\beta=0.16, p<0.001)$. Therefore, H3a and H3b were supported. Second, findings on the impacts of attitude, subjective norms, and personal norms were more complicated. Attitude was positively related to the money donations $(\beta=0.145, p<0.001$ ), confirming H4b. However, the relationship between attitude and time donations was insignificant. Subjective norms showed no significant influence on time donations and money donations; thus, H5a and H5b were not supported. Perceived behavioral control significantly and positively affected time donations $(\beta=0.363, p<0.001)$ and money donations $(\beta=0.189, p<0.001)$, validating hypotheses H6a and H6b. The path from personal norms to the money donations $(\beta=0.262, p<0.001)$ was significant and positive, while personal norms showed no significant influence on time donations. Consequently, H7b was supported and H7a was not.

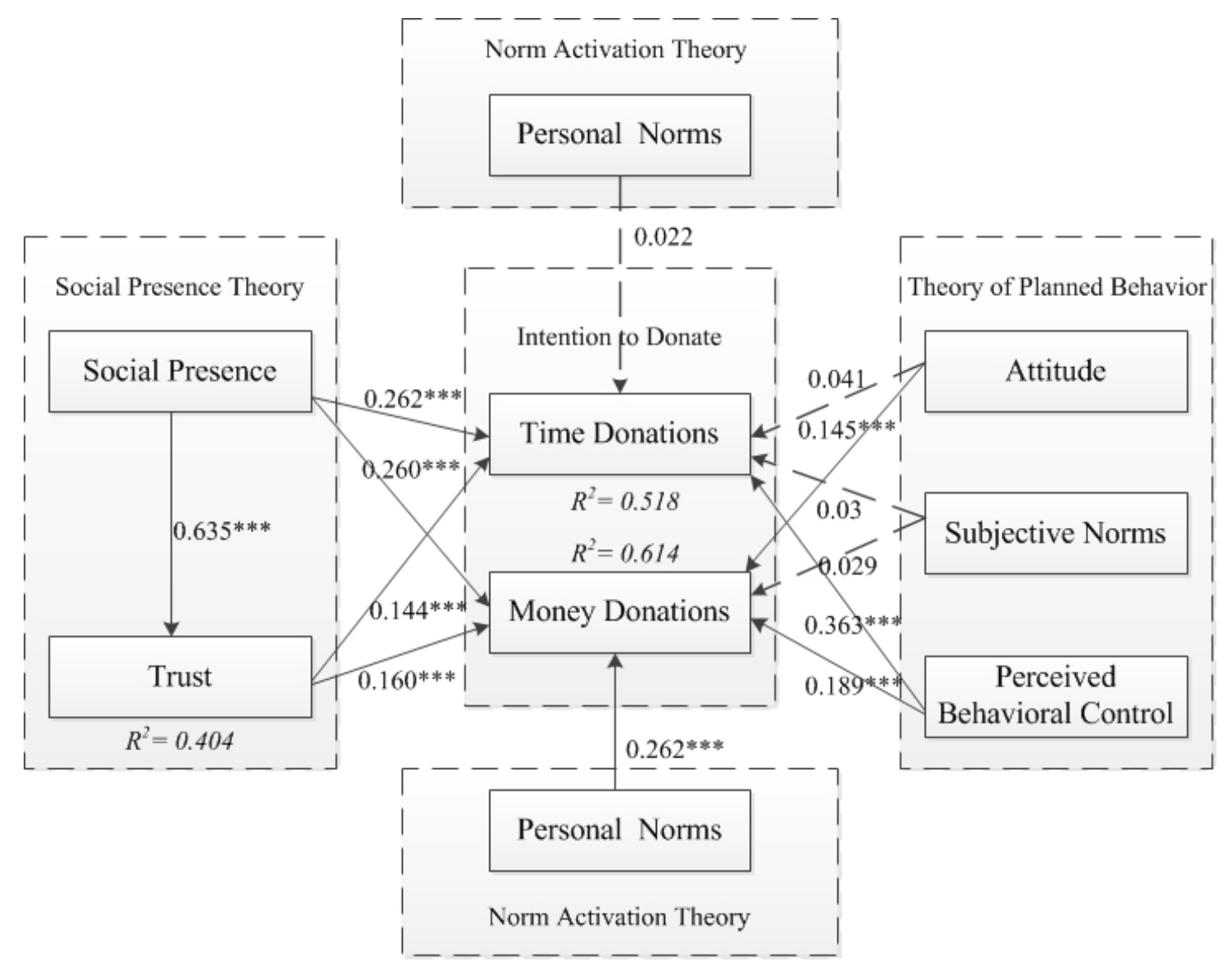

Figure 2. Structural model. Note: ${ }^{*} p<0.05 ;{ }^{* *} p<0.01 ;{ }^{* * *} p<0.001$.

The $R^{2}$ for trust was $40.4 \%$. The proposed model explained $51.8 \%$ of the variance of time donations, and $61.4 \%$ of the variance of money donations. This indicates that our proposed model offers a reasonable explanation of the variance of backers' intention to donate online.

The proposed hypotheses and data analysis results are summarized in Table 4. In summary, the majority of hypotheses were verified and supported, except for the influence of attitude on time donations, the impact of the subjective norms on intention to donate (both time donations and money donations), and the effect of the personal norms on time donations in donation-based crowdfunding. 
Table 4. Summary of the structural model.

\begin{tabular}{|c|c|c|c|}
\hline Dependent Variables & Hypothesis & Description & Results \\
\hline Trust & $\mathrm{H} 2$ & $\begin{array}{l}\text { Social presence positively affects a donor's } \\
\text { trust in donation-based crowdfunding. }\end{array}$ & Yes \\
\hline \multirow{6}{*}{ Time donations } & $\mathrm{H} 1 \mathrm{a}$ & $\begin{array}{l}\text { Social presence positively affects a donor's } \\
\text { intention toward making time donations. }\end{array}$ & Yes \\
\hline & $\mathrm{H} 3 \mathrm{a}$ & $\begin{array}{l}\text { Trust positively affects a donor's intention } \\
\text { toward making time donations. }\end{array}$ & Yes \\
\hline & $\mathrm{H} 4 \mathrm{a}$ & $\begin{array}{l}\text { The attitude positively affects a donor's } \\
\text { intention toward making time donations. }\end{array}$ & No \\
\hline & $\mathrm{H} 5 \mathrm{a}$ & $\begin{array}{l}\text { Subjective norms are positively related to } \\
\text { time donations. }\end{array}$ & No \\
\hline & H6a & $\begin{array}{l}\text { Perceived behavioral control is positively } \\
\text { related to time donations. }\end{array}$ & Yes \\
\hline & $\mathrm{H} 7 \mathrm{a}$ & $\begin{array}{l}\text { Personal norms are positively related to } \\
\text { time donations. }\end{array}$ & No \\
\hline \multirow{6}{*}{ Money donations } & $\mathrm{H} 1 \mathrm{~b}$ & $\begin{array}{l}\text { Social presence positively affects a donor's } \\
\text { intention toward making money donations }\end{array}$ & Yes \\
\hline & $\mathrm{H} 3 \mathrm{~b}$ & $\begin{array}{l}\text { Trust positively affects a donor's intention } \\
\text { toward making money donations. }\end{array}$ & Yes \\
\hline & $\mathrm{H} 4 \mathrm{~b}$ & $\begin{array}{l}\text { Attitude positively affects a donor's } \\
\text { intention toward making money donations. }\end{array}$ & Yes \\
\hline & $\mathrm{H} 5 \mathrm{~b}$ & $\begin{array}{l}\text { Subjective norms are positively related to } \\
\text { money donations. }\end{array}$ & No \\
\hline & $\mathrm{H} 6 \mathrm{~b}$ & $\begin{array}{l}\text { Perceived behavioral control is positively } \\
\text { related to money donations. }\end{array}$ & Yes \\
\hline & $\mathrm{H} 7 \mathrm{~b}$ & $\begin{array}{l}\text { Personal norms are positively related to } \\
\text { money donations. }\end{array}$ & Yes \\
\hline
\end{tabular}

\section{Discussions}

\subsection{Theoretical Implications}

The hypothesis about the effect of attitude toward intention to donate was found to be statistically significant by Bird et al. [83] and Saha and Chandra [53]; however, it was not supported in our analysis. In our study, the significant effect of attitude on money donations matched that of previous studies. Contrary to our expectations, attitude did not have a significant influence on time donations. There are two possible explanations for this diverging result. First, Metzger [84] suggested that users are more confident about network information from experts and are more willing to accept their recommended content. Because the forwarders' judgments on the credibility and authority of website information may be superficial and subjective, they do not want to help in the dissemination of false information. According to the open nature of the cyberspace, certain information can be instantly transmitted, and the explosive spread through the social network will come about quickly, which leads to a certain social impact. Therefore, the forwarder is responsible for the authenticity of the forwarded information. Second, our research focused on millennials, who pay more attention to efficiency, so they decide to give time or money based on the evaluation of lower donation cost. Thus, it is likely that when the volunteer's time price rises, the time donation will be replaced by the money donation [85]. Our study extends the applicability of attitude to donation-based crowdfunding setting and suggests that money donations are the primary factor affected by attitude. 
It is noteworthy that subjective norm has no significant impact on the intention to donate (for both time and money donations), which differs from the findings of other studies. For instance, existing studies report that subjective norms significantly affects backers' donation intentions.

Saha and Chandra [53] found that subjective norms are one of the drivers of blood donors' intention to donate voluntarily. However, social presence has a significant influence on the intention to donate (for both time and money donations). Although, at first glance, the result seems surprising, it explains well the difference between donation-based crowdfunding and conventional charity. One possible explanation may be that the characteristics of virtual cyberspace and network community are such that most individuals are weakly influenced by the pressures that stem from physical social relationships and surroundings. This further highlights the importance of a website providing social presence.

The perception of trust is especially important when it comes to new services or funds-linked services. The main difference between donation-based crowdfunding activities and traditional charity is the online character of the former; others include the acquisition of project information, the browsing of projects, the willingness to donate, and the donation of funds. A significant influence of trust on behavior intention was verified in previous studies $[10,86]$. In this context, social presence has a significant impact on trust, which supports the results of the studies conducted by Choi [39] and Lu et al. [87].

The research findings indicate that personal norms have an insignificant influence on time donations, but a significant impact on money donations. An insignificant effect of this variable on time donations can be justified by the fact that personal norm does not hinder the intention of backers to donate. It essentially relates personal norms to intrinsic motivation, which refers to the overall level of public goods generated by an organization. Bauer et al. [85] indicated that those who did not have jobs were more likely to donate time, while those who worked more than $45 \mathrm{~h}$ were more likely to donate money. Because the majority of the subjects of this study were highly educated, they had their own jobs. Therefore, they mainly took part in money donations to make up for the lack of time donations. Findings from the SEM analysis, which provide the path coefficient and significance levels, show that personal norms exert the strongest influence on money donations, followed by social presence, perceived behavioral control, trust, and attitude. From this, we can infer that when individuals participate in money donations, it is mainly personal norms that play a major role. Higher personal norms will generate a stronger intention to donate money.

Remarkably, the path coefficient from perceived behavioral control to time donations was the largest among all path coefficients. It indicates the donor's ability to perceive time donations. As mentioned above, our survey focused on millennials; because most of them were highly educated, they were busy with school or work. Therefore, it can be inferred that they were particularly sensitive about time. The current study revealed that perceived behavioral control had a significant influence on the intention to donate (for both time and money donations).

\subsection{Managerial Implications}

The results of the study can be useful for fundraisers and platforms. With the rapid development of the Internet and the popularity of mobile phones, donation-based crowdfunding has been popular among the public because it has the advantages of greater transparency, diversified projects, and freedom from time and space constraints. All these will definitely change the operation mechanism of traditional public welfare activities and public undertakings.

First, new donation-based crowdfunding platforms are being created often, such as DonorsChoose, FirstGiving, Crowdrise, and so on. Our results may serve to support crowdfunding platforms' managers in their decisions on whether and how to utilize backers' positive attitudes. It could be a good idea that multiple crowdfunding platforms develop mutual cooperation in the project design and implementation to create a better service environment. By this means, it will help backers obtain more information about certain campaign and build a positive attitude. Additionally, simultaneous crowdfunding projects based on multiple platforms will increase the success rate of fundraising. 
Second, the persuasiveness of the project itself is the main condition for the success of donation-based crowdfunding. The fundraisers should attach great importance to the design of the implementation plan and the scheme of the project promotion plan. The target audience of crowdfunding projects consists of young people who like to focus on creative projects. Therefore, when describing the key features of the project, it is necessary to attract donors through the novelty of project design. Our results indicate that enhancing social presence helps potential backers to generate a greater intention to donate.

Third, trust is obtained by establishing a connection between trustors (a person creating trust and acting in a specific manner under the environmental conditions) and trustees [88]. Funding seekers should make use of real pictures, videos, and sincere words to actively attract visitors to seek information about the projects. Presenting pictures and videos will help backers to improve the perceived trust, which results in enhancing a backer's intention to donate. The crowdfunding platform should focus on building the different aspects of its own credibility. However, the current role of a platform is as a simple intermediary with the process of hosting the project, and collecting and distributing funds. To implement a crowdfunding campaign, it is possible to cooperate with the government and the public to supervise the project, besides allocating project funds in phases according to the actual progress of the project. In addition to updating the donor community during the entire campaign process, it is necessary for the fundraiser to communicate factual information about the usage of donations with backers after the fundraising event ends [89].

Fourth, our research demonstrates that personal norms significantly predicted the intention to donate. Therefore, soft policies, such as publicity and education, can be adopted to promote the awareness of altruism and philanthropy. Engagements of individual donors are essential to the campaign and the individual's donating experience should be captured in the story developed by the fundraiser [89]. Gradually these activities can enlighten more people to participate in donation-based crowdfunding campaigns.

\subsection{Limitations}

As in other empirical studies, there are a few limitations that need to be acknowledged before summarizing our conclusions. First, a major theme of the current paper is offering a description of the underlying dynamics of the potential backer's donation intention for crowdfunding. Benabou and Tirole [90] pointed out that people can get three different types of utility from donation: intrinsic motivation, self-image, and social esteem. Self-image and social esteem are also potential factors that affect backers' intention to donate. Further research, thus, can explain donation intention by including self-image and social esteem. We also summarized the factors influencing the intention to donate in other literature reviews in Table 5. Second, complex social mechanisms also play a role in donation-based crowdfunding, which is not the same as with traditional charity. In traditional philanthropy, charitable activities are often carried out between friends, relatives, and colleagues in real-life relationships. Mollick [91] found that Facebook friends of fundraisers had a certain relationship with the success of the crowdfunding effort, which provides a possible perspective on the size of the social network. Future research can shed light on the role of social networks, such as Facebook, in the context of donation-crowdfunding. Finally, our questionnaires were all filled in by Chinese nationals, and this research may be seen as more of an in-depth study of the Chinese charity landscape. Therefore, there is still doubt about whether its results are generalizable to other cultural backgrounds. Future scholars can study the factors influencing donation intention in charity crowdfunding, compared with those in traditional charity, in different cultural contexts. 
Table 5. Influencing factors of donation intentions.

\begin{tabular}{ccl}
\hline Author & Year & \multicolumn{1}{c}{ Factors } \\
\hline Xu [92] & 2018 & Video, picture, description text, category \\
\hline Gleasure and Feller [65] & 2016 & $\begin{array}{l}\text { Fundraising target, rate of donation, level of disclosure, } \\
\text { campaign imagery, campaign dialogue }\end{array}$ \\
\hline Liu, Suh, and Wagner [10] & 2018 & $\begin{array}{l}\text { Website quality, transaction convenience, initiator reputation, } \\
\text { project popularity, project content quality }\end{array}$ \\
\hline Majumdar and Bose [22] & 2018 & $\begin{array}{l}\text { Money-related discussion, negative emotions, female references, } \\
\text { authenticity, comment received, request popularity, account age } \\
\text { of charity seeker, past participation of charity seeker, text length, } \\
\text { presence of image }\end{array}$ \\
\hline Meer [21] & 2014 & Efficiency price, competition on giving \\
\hline
\end{tabular}

\section{Conclusions}

Considering a lack of underlying theories and theoretical models in the current crowdfunding literature, we seek to fill the gap by investigating the issues of donation-based crowdfunding from a specific theoretical perspective. Compared with the extant literature, this is a confirmatory study, based on a solid theoretical foundation, to test the role of several factors in the donation intentions of funders. First, a categorical analysis of philanthropic acts reveals significant differences in the determinants and relationships between time and money donations. The present paper finds that trust, social presence, and perceived behavioral control are positively and significantly related to time donations. For the dependent variable of money donations, subjective norms alone had an insignificant effect among the six variables.

Second, this paper is also one of the first to apply SPT in the donation-based crowdfunding context. In prior literature, researchers have already verified the influence of social presence in the online trading context. We extend the prior literature to a donation-based crowdfunding context. Taking social presence as the key factor influencing a backer's intention to donate will prominently highlight the unique feature of online crowdfunding and significantly distinguish it from traditional philanthropy.

Further, most previous articles on charitable donations adopted TPB, whereas this paper adopted SPT and NAT as the complementary theoretical concepts. The present study may also illustrate the differences between traditional charity and donation-based crowdfunding from the perspective of the TPB model. We contribute toward the study of factors that influence a backer's intention to donate by comparing donation crowdfunding with traditional charity, and combining TPB, SPT, and NAT.

Author Contributions: Conceptualization, Y.C.; Methodology, R.D.; Project administration, J.Y. and Y.L.; Writing-original draft, R.D.; Writing-review and editing, Y.C. and Y.L.

Funding: This research was funded by the National Social Science Foundation of China, grant number 17BGL197.

Acknowledgments: The authors would like to thank the editors and the anonymous reviewers of this journal.

Conflicts of Interest: The authors declare no conflict of interest. 


\section{Appendix A}

Table A1. Scales and items.

\begin{tabular}{|c|c|c|}
\hline Construct & Items & Source \\
\hline Attitude & $\begin{array}{l}\text { Donating can make me feel happy. } \\
\text { It's good to donate. } \\
\text { I would like to do my best to donate. } \\
\text { I would like to encourage people around me to donate. }\end{array}$ & $\begin{array}{l}\text { Wang et al. } \\
\text { (2018) [64] }\end{array}$ \\
\hline Subjective Norms & $\begin{array}{l}\text { Most of the people who have important influence on me will donate. } \\
\text { My family encourages me to donate. } \\
\text { My friends around me encourage me to donate. } \\
\text { The government actively advocates and implements help others in need. }\end{array}$ & $\begin{array}{l}\text { Wang et al. } \\
\text { (2018) [64] }\end{array}$ \\
\hline Personal Norms & $\begin{array}{l}\text { I think I have the consciousness of taking pleasure in helping people. } \\
\text { I think I have a sense of benevolence. } \\
\text { I think I can contribute to helping people through donating. } \\
\text { I think I have the duty to donate. }\end{array}$ & $\begin{array}{l}\text { Wang et al. } \\
\text { (2018) [64] }\end{array}$ \\
\hline $\begin{array}{c}\text { Perceived } \\
\text { behavioral control }\end{array}$ & $\begin{array}{l}\text { If I wanted to, I could easily donate money and time to donation-based } \\
\text { crowdfunding. } \\
\text { It is mostly up to me whether I donate money or time to donation-based } \\
\text { crowdfunding. } \\
\text { I am confident that I will be able to donate money and time to } \\
\text { donation-based crowdfunding. } \\
\text { Donating money and time to donation-based crowdfunding is easy for } \\
\text { me to do. }\end{array}$ & $\begin{array}{l}\text { Mittelman and } \\
\text { Rojas-Méndez } \\
\text { (2018) [74] }\end{array}$ \\
\hline Social Presence & $\begin{array}{l}\text { There is a sense of human contact in the donation-based } \\
\text { crowdfunding platforms. } \\
\text { There is a sense of personalness in the donation-based } \\
\text { crowdfunding platforms. } \\
\text { There is a sense of sociability in the donation-based } \\
\text { crowdfunding platforms. } \\
\text { There is a sense of human warmth in the donation-based } \\
\text { crowdfunding platforms. } \\
\text { There is a sense of human sensitivity in the donation-based } \\
\text { crowdfunding platforms. }\end{array}$ & $\begin{array}{l}\text { Gefen and } \\
\text { Straub } \\
(2004)[38]\end{array}$ \\
\hline Trust & $\begin{array}{l}\text { The donation-based crowdfunding is trustworthy. } \\
\text { The donation-based crowdfunding keeps its promise. } \\
\text { The donation-based crowdfunding is convincing. }\end{array}$ & Lee (2005) [75] \\
\hline Time Donations & $\begin{array}{l}\text { The probability that I would donate time (including the forwarding of } \\
\text { crowdfunding information) to the crowdfunding project is high. } \\
\text { My willingness to donate time (including the forwarding of } \\
\text { crowdfunding information) to the crowdfunding project is high. } \\
\text { The likelihood of my donating time (including the forwarding of } \\
\text { crowdfunding information) to the crowdfunding project is high. }\end{array}$ & $\begin{array}{l}\text { Liu et al. } \\
\text { (2018) [10] }\end{array}$ \\
\hline Money Donations & $\begin{array}{l}\text { The probability that I would donate money to the crowdfunding project } \\
\text { is high. } \\
\text { My willingness to donate money to the crowdfunding project is high. } \\
\text { The likelihood of my donating money to the crowdfunding project is high. }\end{array}$ & $\begin{array}{l}\text { Liu et al. } \\
\text { (2018) [10] }\end{array}$ \\
\hline
\end{tabular}




\section{Appendix B}

Table A2. Loadings and cross-loadings.

\begin{tabular}{|c|c|c|c|c|c|c|c|c|}
\hline Factor & AT & MD & PBC & PN & SN & SP & TD & TR \\
\hline AT1 & 0.811 & 0.54 & 0.499 & 0.609 & 0.553 & 0.477 & 0.421 & 0.446 \\
\hline AT2 & 0.603 & 0.312 & 0.246 & 0.498 & 0.358 & 0.33 & 0.187 & 0.294 \\
\hline AT3 & 0.84 & 0.52 & 0.476 & 0.628 & 0.598 & 0.439 & 0.408 & 0.465 \\
\hline AT4 & 0.829 & 0.522 & 0.492 & 0.585 & 0.591 & 0.475 & 0.454 & 0.507 \\
\hline MD1 & 0.566 & 0.914 & 0.596 & 0.624 & 0.568 & 0.614 & 0.651 & 0.561 \\
\hline MD2 & 0.557 & 0.889 & 0.586 & 0.597 & 0.522 & 0.62 & 0.663 & 0.593 \\
\hline MD3 & 0.569 & 0.908 & 0.589 & 0.596 & 0.52 & 0.621 & 0.637 & 0.555 \\
\hline PBC1 & 0.501 & 0.546 & 0.857 & 0.529 & 0.527 & 0.548 & 0.596 & 0.532 \\
\hline PBC2 & 0.328 & 0.342 & 0.558 & 0.427 & 0.29 & 0.425 & 0.251 & 0.34 \\
\hline РBC3 & 0.503 & 0.584 & 0.828 & 0.559 & 0.492 & 0.563 & 0.607 & 0.489 \\
\hline PBC4 & 0.394 & 0.494 & 0.791 & 0.446 & 0.484 & 0.5 & 0.478 & 0.395 \\
\hline PN1 & 0.615 & 0.516 & 0.513 & 0.81 & 0.513 & 0.534 & 0.448 & 0.469 \\
\hline PN2 & 0.527 & 0.462 & 0.455 & 0.773 & 0.449 & 0.492 & 0.357 & 0.417 \\
\hline PN3 & 0.6 & 0.554 & 0.494 & 0.799 & 0.516 & 0.526 & 0.397 & 0.5 \\
\hline PN4 & 0.577 & 0.55 & 0.523 & 0.742 & 0.553 & 0.452 & 0.481 & 0.549 \\
\hline SN1 & 0.563 & 0.483 & 0.508 & 0.547 & 0.824 & 0.514 & 0.446 & 0.524 \\
\hline SN2 & 0.572 & 0.529 & 0.486 & 0.533 & 0.854 & 0.468 & 0.441 & 0.487 \\
\hline SN3 & 0.526 & 0.452 & 0.513 & 0.489 & 0.809 & 0.426 & 0.408 & 0.431 \\
\hline SN4 & 0.499 & 0.374 & 0.335 & 0.481 & 0.608 & 0.474 & 0.242 & 0.403 \\
\hline SP1 & 0.396 & 0.51 & 0.557 & 0.445 & 0.479 & 0.794 & 0.528 & 0.53 \\
\hline SP2 & 0.417 & 0.487 & 0.555 & 0.432 & 0.45 & 0.767 & 0.493 & 0.474 \\
\hline SP3 & 0.424 & 0.458 & 0.527 & 0.468 & 0.458 & 0.776 & 0.483 & 0.443 \\
\hline SP4 & 0.464 & 0.6 & 0.485 & 0.56 & 0.496 & 0.773 & 0.497 & 0.52 \\
\hline SP5 & 0.448 & 0.563 & 0.421 & 0.552 & 0.404 & 0.727 & 0.423 & 0.463 \\
\hline TD1 & 0.415 & 0.626 & 0.591 & 0.441 & 0.469 & 0.566 & 0.891 & 0.475 \\
\hline TD2 & 0.459 & 0.656 & 0.587 & 0.503 & 0.437 & 0.572 & 0.892 & 0.521 \\
\hline TD3 & 0.445 & 0.64 & 0.582 & 0.508 & 0.44 & 0.552 & 0.889 & 0.496 \\
\hline TR1 & 0.56 & 0.604 & 0.567 & 0.614 & 0.566 & 0.616 & 0.53 & 0.915 \\
\hline TR2 & 0.478 & 0.554 & 0.504 & 0.531 & 0.517 & 0.551 & 0.495 & 0.893 \\
\hline TR3 & 0.464 & 0.526 & 0.476 & 0.523 & 0.501 & 0.53 & 0.469 & 0.871 \\
\hline
\end{tabular}

Note: $\mathrm{AT}=$ Attitude $\mathrm{MD}=$ Money donation $; \mathrm{PBC}=$ Perceived behavioral control; $\mathrm{PN}=$ Personal norms; $\mathrm{SN}=$ Subjective norms; $\mathrm{SP}=$ Social presence; $\mathrm{TD}=$ Time donation; $\mathrm{TR}=$ Trust.

\section{References}

1. Vlaholias, E.; Thompson, K.; Every, D.; Dawson, D. Charity Starts ... at Work? Conceptual Foundations for Research with Businesses that Donate to Food Redistribution Organisations. Sustainability 2015, 7, 7997-8021. [CrossRef]

2. Bi, S.; Liu, Z.; Usman, K. The influence of online information on investing decisions of reward-based crowdfunding. J. Bus. Res. 2017, 71, 10-18. [CrossRef]

3. Zhongchoujia.com. Available online: http://www.zhongchoujia.com/data/31205.html (accessed on 9 June 2019).

4. Belleflamme, P.; Lambert, T.; Schwienbacher, A. Crowdfunding: Tapping the right crowd. CORE Discuss. Pap. 2011, 29, 585-609.

5. Ariely, D.; Bracha, A.; Meier, S. Doing Good or Doing Well? Image Motivation and Monetary Incentives in Behaving Prosocially. Am. Econ. Rev. 2009, 99, 544-555. [CrossRef]

6. Kuppuswamy, V.; Bayus, B.L. Crowdfunding Creative Ideas: The Dynamics of Project Backers. In The Economics of Crowdfunding: Startups, Portals and Investor Behavior, 1st ed.; Cumming, D., Hornuf, L., Eds.; Springer: Cham, Switzerland, 2018; pp. 151-182.

7. Sasaki, S. Majority size and conformity behavior in charitable giving: Field evidence from a donation-based crowdfunding platform in Japan. J. Econ. Psychol. 2019, 70, 36-51. [CrossRef]

8. Agrawal, A.; Catalini, C.; Goldfarb, A. Crowdfunding: Geography, Social Networks, and the Timing of Investment Decisions. J. Econ. Manag. Strat. 2015, 24, 253-274. [CrossRef] 
9. Funk, A.S. Crowdfunding in China: A New Institutional Economics Approach; Springer: Berlin/Heidelberg, Germany, 2019.

10. Liu, L.; Suh, A.; Wagner, C. Empathy or perceived credibility? An empirical study on individual donation behavior in charitable crowdfunding. Internet Res. 2018, 28, 623-651. [CrossRef]

11. Tsai, K.S.; Wang, Q. Charitable Crowdfunding in China: An Emrgent Channel for Setting Policy Agendas? China Q. 2019, 1-31. [CrossRef]

12. Maes, J.; Leroy, H.; Sels, L. Gender differences in entrepreneurial intentions: A TPB multi-group analysis at factor and indicator level. Eur. Manag. J. 2014, 32, 784-794. [CrossRef]

13. Lorenz, B.A.; Hartmann, M.; Simons, J. Impacts from region-of-origin labeling on consumer product perception and purchasing intention-Causal relationships in a TPB based model. Food Qual. Prefer. 2015, 45, 149-157. [CrossRef]

14. Wu, J.-H.; Cheng, C.-M.; Cheng, P.-J. Behavioral intention toward urban eco-land performance assessment models using TPB tests. J. Bus. Res. 2015, 68, 771-776. [CrossRef]

15. Onwezen, M.C.; Antonides, G.; Bartels, J. The Norm Activation Model: An exploration of the functions of anticipated pride and guilt in pro-environmental behaviour. J. Econ. Psychol. 2013, 39, 141-153. [CrossRef]

16. Van Der Werff, E.; Steg, L. One model to predict them all: Predicting energy behaviours with the norm activation model. Energy Res. Soc. Sci. 2015, 6, 8-14. [CrossRef]

17. Cyr, D.; Hassanein, K.; Head, M.; Ivanov, A. The role of social presence in establishing loyalty in e-Service environments. Interact. Comput. 2007, 19, 43-56. [CrossRef]

18. Hassanein, K.; Head, M. Manipulating perceived social presence through the web interface and its impact on attitude towards online shopping. Int. J. Hum.-Comput. Stud. 2007, 65, 689-708. [CrossRef]

19. Silvio, V. Sustainability in Equity Crowdfunding. Technol. Forecast. Soc. Chang. 2019, 141, 98-106.

20. Barman, E. The social bases of philanthropy. Annu. Rev. Sociol. 2017, 43, 271-290. [CrossRef]

21. Meer, J. Effects of the price of charitable giving: Evidence from an online crowdfunding platform. J. Econ. Behav. Organ. 2014, 103, 113-124. [CrossRef]

22. Majumdar, A.; Bose, I. My words for your pizza: An analysis of persuasive narratives in online crowdfunding. Inf. Manag. 2018, 55, 781-794. [CrossRef]

23. Michaelidou, N.; Micevski, M.; Siamagka, N.T. Consumers' intention to donate to two children's charity brands: A comparison of Barnardo's and BBC Children in Need. J. Prod. Brand Manag. 2015, 24, 134-146. [CrossRef]

24. Michel, G.; Rieunier, S. Nonprofit brand image and typicality influences on charitable giving. J. Bus. Res. 2012, 65, 701-707. [CrossRef]

25. Liu, W.; Aaker, J. The Happiness of Giving: The Time-Ask Effect. J. Consum. Res. 2008, 35, 543-557. [CrossRef]

26. Feldman, N.E. Time is money: Choosing between charitable activities. Am. Econ. J. Econ. Policy 2010, 2, 103-130. [CrossRef]

27. Brown, A.L.; Meer, J.; Williams, J.F. Why Do People Volunteer? An Experimental Analysis of Preferences for Time Donations. Manag. Sci. 2019, 65, 1455-1468. [CrossRef]

28. Bryant, W.K.; Jeon-Slaughter, H.; Kang, H.; Tax, A. Participation in Philanthropic Activities: Donating Money and Time. J. Consum. Policy 2003, 26, 43-73. [CrossRef]

29. Short, J.; Williams, E.; Christie, B. The Social Psychology of Telecommunications; John Wiley \& Sons: London, UK, 1976.

30. Komiak, S.Y.X.; Benbasat, I. The Effects of Personalization and Familiarity on Trust and Adoption of Recommendation Agents. Mis Q. 2006, 30, 941-960. [CrossRef]

31. Kumar, N.; Benbasat, I. Research Note: The Influence of Recommendations and Consumer Reviews on Evaluations of Websites. Inf. Syst. Res. 2006, 17, 425-439. [CrossRef]

32. Schroeder, R. Being There Together and the Future of Connected Presence. Presence 2006, 15, $438-454$. [CrossRef]

33. Animesh, A.; Pinsonneault, A.; Yang, S.B.; Oh, W. An Odyssey into Virtual Worlds: Exploring the Impacts of Technological and Spatial Environments. Mis Q. 2011, 35, 789-810. [CrossRef]

34. Heijden, H.V.D. User Acceptance of Hedonic Information Systems. Mis Q. 2004, 28, 695-704. [CrossRef]

35. Cui, G.; Meng, C. Building modern online social presence: A review of social presence theory and its instructional design implications for future trends. Educ. Inf. Technol. 2013, 18, 661-685. [CrossRef] 
36. Chang, C.-M.; Hsu, M.-H. Understanding the determinants of users' subjective well-being in social networking sites: An integration of social capital theory and social presence theory. Behav. Inf. Technol. 2016, 35, 720-729. [CrossRef]

37. Tu, C.-H. On-line learning migration: From social learning theory to social presence theory in a CMC environment. J. Netw. Comput. Appl. 2000, 23, 27-37. [CrossRef]

38. Gefen, D.; Straub, D.W. Consumer trust in B2C e-Commerce and the importance of social presence: Experiments in e-Products and e-Services. Omega 2004, 32, 407-424. [CrossRef]

39. Choi, S. The flipside of ubiquitous connectivity enabled by smartphone-based social networking service: Social presence and privacy concern. Comput. Hum. Behav. 2016, 65, 325-333. [CrossRef]

40. Wang, L.C.; Baker, J.; Wagner, J.A.; Wakefield, K. Can a Retail Web Site Be Social? J. Mark. 2007, 71, $143-157$. [CrossRef]

41. Gefen, D.; Straub, D. Managing User Trust in B2C e-Services. e-Service J. 2003, 2, 7-24. [CrossRef]

42. Gvili, Y.; Levy, S. Antecedents of attitudes toward eWOM communication: Differences across channels. Internet Res. 2016, 26, 1030-1051. [CrossRef]

43. Kim, J.G.; Kong, H.K.; Karahalios, K.; Fu, W.T.; Hong, H. The Power of Collective Endorsements: Credibility Factors in Medical Crowdfunding Campaigns. In Proceedings of the $2016 \mathrm{CHI}$ Conference on Human Factors in Computing Systems, San Jose, CA, USA, 7-12 May 2016; pp. 4538-4549.

44. Jarvenpaa, S.L.; Tractinsky, N.; Vitale, M. Consumer trust in an Internet store. J. Comput.-Mediat. Commun. 1999, 5, 45-71.

45. Singh, J.; Sirdeshmukh, D. Agency and Trust Mechanisms in Consumer Satisfaction and Loyalty Judgments. J. Acad. Mark. Sci. 2000, 28, 150-167. [CrossRef]

46. Choi, J.; Lee, H.J.; Kim, Y.C. The Influence of Social Presence on Customer Intention to Reuse Online Recommender Systems: The Roles of Personalization and Product Type. Int. J. Electron. Commer. 2014, 16, 129-154. [CrossRef]

47. Sullivan, Y.W.; Kim, D.J. Assessing the effects of consumers' product evaluations and trust on repurchase intention in e-commerce environments. Int. J. Inf. Manag. 2018, 39, 199-219. [CrossRef]

48. Ajzen, I. The theory of planned behavior. Organ. Behav. Hum. Decis. Process. 1991, 50, 179-211. [CrossRef]

49. Chen, M.-F.; Tung, P.-J. Developing an extended Theory of Planned Behavior model to predict consumers' intention to visit green hotels. Int. J. Hosp. Manag. 2014, 36, 221-230. [CrossRef]

50. Paul, J.; Modi, A.; Patel, J. Predicting green product consumption using theory of planned behavior and reasoned action. J. Retail. Consum. Serv. 2016, 29, 123-134. [CrossRef]

51. Webb, D.J.; Green, C.L.; Brashear, T.G. Development and Validation of Scales to Measure Attitudes Influencing Monetary Donations to Charitable Organizations. J. Acad. Mark. Sci. 2000, 28, 299-309. [CrossRef]

52. Kotchen, M.J.; Reiling, S.D. Environmental attitudes, motivations, and contingent valuation of nonuse values: A case study involving endangered species. Ecol. Econ. 2000, 32, 93-107. [CrossRef]

53. Saha, S.; Chandra, B. Understanding the underlying motives and intention among Indian blood donors towards voluntary blood donation: A cross-sectional study. Transfus. Clin. Biol. 2018, 25, 109-117. [CrossRef]

54. Fishbein, M.; Ajzen, I. Belief, attitude, intention, and behavior: An introduction to the theory and research. Philos. Rhetor. 1977, 10, 130-132.

55. Ajzen, I. Nature and operation of attitudes. Annu. Rev. Psychol. 2001, 52, 27-58. [CrossRef]

56. Han, H.; Kim, Y. An investigation of green hotel customers' decision formation: Developing an extended model of the theory of planned behavior. Int. J. Hosp. Manag. 2010, 29, 659-668. [CrossRef]

57. Dean, M.; Raats, M.; Shepherd, R. The Role of Self-Identity, Past Behavior, and Their Interaction in Predicting Intention to Purchase Fresh and Processed Organic Food. J. Appl. Soc. Psychol. 2012, 42, 669-688. [CrossRef]

58. Ha, H.-Y.; Janda, S. Predicting Consumer Intentions to Purchase Energy-Efficient Products. J. Consum. Mark. 2017, 29, 461-469. [CrossRef]

59. Teng, Y.M.; Wu, K.S.; Liu, H.H. Integrating altruism and the theory of planned behavior to predict patronage intention of a green hotel. J. Hosp. Tour. Res. 2015, 39, 299-315. [CrossRef]

60. Albayrak, T.; Aksoy, S.; Caber, M. The effect of environmental concern and scepticism on green purchase behaviour. Mark. Intell. Plan. 2013, 31, 27-39. [CrossRef]

61. Harland, P.; Staats, H.; Wilke, H.A.M. Explaining Proenvironmental Intention and Behavior by Personal Norms and the Theory of Planned Behavior. J. Appl. Soc. Psychol. 1999, 29, 2505-2528. [CrossRef]

62. Schwartz, S.H. Normative Influences on Altruism. Adv. Exp. Soc. Psychol. 1977, 10, 221-279. 
63. Park, J.; Ha, S. Understanding Consumer Recycling Behavior: Combining the Theory of Planned Behavior and the Norm Activation Model. Fam. Consum. Sci. Res. J. 2014, 42, 278-291. [CrossRef]

64. Wang, B.; Wang, X.; Guo, D.; Zhang, B.; Wang, Z. Analysis of factors influencing residents' habitual energy-saving behaviour based on NAM and TPB models: Egoism or altruism? Energy Policy 2018, 116, 68-77. [CrossRef]

65. Gleasure, R.; Feller, J. Does Heart or Head Rule Donor Behaviors in Charitable Crowdfunding Markets? Int. J. Electron. Commer. 2016, 20, 499-524. [CrossRef]

66. De Groot, J.I.M.; Steg, L. Morality and Prosocial Behavior: The Role of Awareness, Responsibility, and Norms in the Norm Activation Model. J. Soc. Psychol. 2009, 149, 425-449. [CrossRef]

67. Doran, R.; Larsen, S. The Relative Importance of Social and Personal Norms in Explaining Intentions to Choose Eco-Friendly Travel Options. Int. J. Tour. Res. 2016, 18, 159-166. [CrossRef]

68. Fishbein, M. Attitude and the prediction of behavior. In Readings in Attitude Theory and Measurement; John Wiley \& Sons: New York, NY, USA, 1967; pp. 447-492.

69. Schwartz, S.H.; Howard, J.A. A normative decision-making model of altruism. In Altruism and Helping Behavior; Lawrence Erbaum: Hillsdale, NJ, USA, 1981; pp. 89-211.

70. Liu, Y.; Sheng, H.; Mundorf, N.; Redding, C.; Ye, Y. Integrating Norm Activation Model and Theory of Planned Behavior to Understand Sustainable Transport Behavior: Evidence from China. Int. J. Environ. Res. Public Health 2017, 14, 1593. [CrossRef]

71. Amos, O.M. Empirical analysis of motives underlying individual contributions to charity. Atl. Econ. J. 1982, 10, 45-52. [CrossRef]

72. Dawson, S. Four motivations for charitable giving: Implications for marketing strategy to attract monetary donations for medical research. J. Health Care Mark. 1988, 8, 31-37.

73. Parker, D.; Manstead, A.S.R.; Stradling, S.G. Extending the Theory of Planned Behavior: The role of personal norm. Br. J. Soc. Psychol. 2011, 34, 127-138. [CrossRef]

74. Mittelman, R.; Rojas-Méndez, J. Why Canadians give to charity: An extended theory of planned behaviour model. Int. Rev. Public Nonprofit Mark. 2018, 15, 189-204. [CrossRef]

75. Lee, T. The Impact of Perceptions of Interactivity on Customer Trust and Transaction Intentions in Mobile Commerce. J. Electron. Commer. Res. 2005, 6, 165-180.

76. Gefen, D.; Straub, D. A Practical Guide to Factorial Validity Using PLS-Graph: Tutorial and Annotated Example. Commun. Assoc. Inf. Syst. 2005, 16, 91-109. [CrossRef]

77. Chang, Y.-W.; Hsu, P.-Y.; Yang, Q.-M. Integration of online and offline channels: A view of O2O commerce. Internet Res. 2018, 28, 926-945. [CrossRef]

78. Gefen, D.; Straub, D.; Boudreau, M.-C. Structural Equation Modeling and Regression: Guidelines for Research Practice. Commun. Assoc. Inf. Syst. 2000, 4, 2-77. [CrossRef]

79. Tenenhaus, M.; Vinzi, V.E.; Chatelin, Y.M.; Lauro, C. PLS path modeling. Comput. Stat. Data Anal. 2005, 48, 159-205. [CrossRef]

80. Henseler, J.; Sarstedt, M. Goodness-of-fit indices for partial least squares path modeling. Comput. Stat. 2013, 28, 565-580. [CrossRef]

81. Wetzels, M.; Odekerken-Schroder, G.; van Oppen, C. Using PLS path modeling for assessing hierarchical construct models: Guidelines and empirical illustration. Mis Q. 2009, 33, 177-195. [CrossRef]

82. Maziriri, E.T.; Madinga, N.W. Data to model the prognosticators of luxury consumption: A partial least squares-structural equation modelling approach (PLS-SEM). Data Brief 2018, 21, 753-757. [CrossRef]

83. Bird, E.L.; Panter, J.; Baker, G.; Jones, T.; Ogilvie, D. Predicting walking and cycling behaviour change using an extended Theory of Planned Behaviour. J. Transp. Health 2018, 10, 11-27. [CrossRef]

84. Metzger, M.J. Making sense of credibility on the Web: Models for evaluating online information and recommendations for future research. J. Am. Soc. Inf. Sci. Technol. 2007, 58, 2078-2091. [CrossRef]

85. Bauer, T.K.; Bredtmann, J.; Schmidt, C.M. Time vs. money-The supply of voluntary labor and charitable donations across Europe. Eur. J. Political Econ. 2013, 32, 80-94. [CrossRef]

86. Chong, A.Y.-L.; Chan, F.T.; Ooi, K.-B. Predicting consumer decisions to adopt mobile commerce: Cross country empirical examination between China and Malaysia. Decis. Support Syst. 2012, 53, 34-43. [CrossRef]

87. Lu, B.; Fan, W.; Zhou, M. Social presence, trust, and social commerce purchase intention: An empirical research. Comput. Hum. Behav. 2016, 56, 225-237. [CrossRef] 
88. Amin, F.; Ahmad, A.; Choi, G.S. Towards Trust and Friendliness Approaches in the Social Internet of Things. Appl. Sci. 2019, 9, 166. [CrossRef]

89. Crowdfunding in UNDP_-Guidance for Project Managers. Available online: https://www.sdfinance.undp. org/content/dam/sdfinance/doc/Crowdfunding\%20in\%20UNDP\%20-\%20Guidance\%20for\%20Project\% 20Managers.pdf (accessed on 29 June 2019).

90. Benabou, R.; Tirole, J. Incentives and prosocial behavior. Am. Econ. Rev. 2006, 96, 1652-1678. [CrossRef]

91. Mollick, E. The dynamics of crowdfunding: An exploratory study. J. Bus. Ventur. 2014, 29, 1-16. [CrossRef]

92. Xu, L.Z. Will a digital camera cure your sick puppy? Modality and category effects in donation-based crowdfunding. Telemat. Inform. 2018, 35, 1914-1924. [CrossRef]

(C) 2019 by the authors. Licensee MDPI, Basel, Switzerland. This article is an open access article distributed under the terms and conditions of the Creative Commons Attribution (CC BY) license (http://creativecommons.org/licenses/by/4.0/). 